\title{
Monteiro Lobato e Paulo Freire: problematizando O Poço do Visconde
}

\section{Monteiro Lobato and Paulo Freire: problematizing O Poço do Visconde}

\author{
Marcelo P. da Silveira e João Zanetic
}

\begin{abstract}
Resumo: Nos últimos anos, várias pesquisas sobre a prática de leitura na formação de professores de Ciências revelam a importância de se promover estudos mais específicos sobre o papel da leitura nos cursos de Licenciatura. Os estudos sobre as relações entre Literatura e Ciência indicam que o texto literário pode promover a leitura e contribuir para o ensino, aprendizagem e formação de professores dedicados à educação científica. Desta forma, buscamos investigar o potencial pedagógico que o livro O Poço do Visconde apresenta para o ensino da Química, discutindo a "veia pedagógica" de Monteiro Lobato e a aproximação que se pode fazer com a pedagogia de Paulo Freire, no sentido de mostrar que ambos, escritor e pedagogo, defendiam a curiosidade como forma de manter o interesse do aluno e/ou criança na busca pelo conhecimento, por meio do diálogo centrado na pedagogia da pergunta. A análise desenvolvida permite interpretar que o livro apresenta uma abordagem pedagógica atual que possibilita discutir questões sobre a problematização e o papel da pergunta e curiosidade nas situações de ensino e aprendizagem por meio do tema petróleo. O Poço do Visconde apresenta o conhecimento científico permeado por discussões que envolvem aspectos econômicos, culturais, políticos e sociais de um determinado contexto histórico, possibilitando promover discussões de caráter mais humanístico no ensino e formação de futuros professores de Química.
\end{abstract}

Palavra Chave: Literatura, pedagogia da pergunta, petróleo, Monteiro Lobato, ensino de química.

\begin{abstract}
In recent years, several articles about the practice of reading in the education of science teachers have revealed the importance of promoting more specific studies about the role of reading in teaching courses. Studies about the relationships between literature and science indicate that the literary text can promote reading and contribute to the teaching, learning and education of teachers dedicated to scientific education. Thus, we investigate the pedagogical potential that the book $O$ Poço do Visconde presents in chemistry teaching, discussing the pedagogical style of Monteiro Lobato and the approximation that can be done with the pedagogy of Paulo Freire, in the sense of showing that both writer and pedagogue defended curiosity as a way to keep the interest of the student and/or child in their search for knowledge, by means of a dialog centered on question pedagogy. The analysis that was developed allows the interpretation that the book presents a current pedagogical approach that enables the discussion of questions about problematization and the role of the question and curiosity in teaching and learning situations, by means of the theme petroleum. O Poço do Visconde presents scientific knowledge permeated by discussions that involve economic, cultural, political and social aspects of a certain historical context, enabling the promotion of more humanistic discussions in the teaching and education of future chemistry teachers.
\end{abstract}

Keywords: Literature, question pedagogy, petroleum, Monteiro Lobato, chemistry teaching.

\footnotetext{
Marcelo Pimentel da Silveira (martzelops@ gmail.com), bacharel em Química pela UNESP Araraquara, licenciado em Química pela Faculdade Oswaldo Cruz, mestre e doutor em Ensino de Ciências pela USP, atualmente é professor adjunto da Universidade Estadual de Maringá (UEM). Maringá, PR - BR. João Zanetic (zanetic@if.usp.br), graduação em Física pelo Instituto de Física da Universidade de São Paulo (IFUSP), mestrado em Física pelo IFUSP, mestrado em Science Education pela University of London, doutor em Ensino de Física pela Faculdade de Educação da USP, atualmente é professor sênior do IFUSP, São Paulo, SP - BR. Recebido em 29/07/2015, aceito em 20/06/2016
}

A seção "Cadernos de Pesquisa" é um espaço dedicado exclusivamente para artigos inéditos (empíricos, de revisão ou teóricos) que apresentem profundidade teórico-metodológica, gerem conhecimentos novos para a área e contribuições para o avanço da pesquisa em Ensino de Química. 
As questões sobre leitura e aprendizagem no âmbito do ensino de química vêm se consolidando como objeto de pesquisa, como indicam alguns estudos. Por exemplo, Andrade e Martins (2004) analisaram o discurso de professores de química, física e biologia sobre leitura; Teixeira Júnior e Silva (2007) traçaram o perfil de leitores em um curso de Licenciatura em Química e Flôr (2009) fez um estudo sobre a leitura e a formação de leitores em aulas de química no Ensino Médio.

Teixeira Júnior e Silva (2007) afirmam que existe uma deficiência na prática de leitura na formação de professores de química, pois por natureza própria do curso, a ênfase está centrada no desenvolvimento de habilidades quantitativas, tais como o uso de cálculos. Quando ocorrem práticas de leitura na formação inicial "os licenciandos assinalam que a maioria dos formadores incentiva apenas a leitura do livro didático da disciplina por eles lecionada" (Teixeira Júnior; Silva, 2007, p. 1367).

Os estudos revelam que trabalhos sobre a leitura nos cursos de química, de uma forma geral, envolvem a problematização de artigos científicos em disciplinas específicas da química (Queiroz; Sá; Santos, 2006); a promoção da argumentação no ensino superior de química por meio do uso de artigos científicos (Queiroz; Santos, 2007) e artigos científicos como recurso didático (Ferreira; Queiroz, 2011; Massi et al., 2009).

Pinto Neto (2008) argumenta que a literatura pode ser uma alternativa de leitura na formação do professor de química, uma vez que o processo de formação também deve ser visto como um espaço para ampliar a cultura do futuro professor, de tal maneira que, possa tomar contato "[...] com diferentes formas de ver, pensar e representar o mundo. Sendo que ao final do processo será este conjunto de experiências, de cunho estético, moral, ético e cultural que irão compor a bagagem do professor" (Pinto Neto, 2008, p.01).

Silva (1998) defende a tese de que todo professor, independente da disciplina que ensina, é um professor de leitura e afirma que questões atuais em torno da interdisciplinaridade apontam para a necessidade de superar visões compartimentalizadas que prevalecem nas escolas, pois o desafio de formar leitores críticos exige "[...] a escola como um todo - com todos os seus professores, de todas as disciplinas - assumir responsavelmente o ensino e os programas relacionados à educação dos leitores" (Silva, 1998, p. 107).

A ciência e a literatura possuem linguagens específicas, entretanto, quando existe interação entre uma e outra área, é possível haver um ganho de humanidade ao conhecimento científico (Galvão, 2006), uma vez que aumentam as possibilidades de fazer diferentes leituras a partir das duas abordagens. A ponte entre ciência e literatura pode, portanto:

[...] trazer a ciência aos cidadãos de outra maneira, sem a imposição da ciência em si mesma, diluindo-a no romance, embora sem a desvirtuar. Sem se fazer a apologia da descaracterização da abordagem científica, indispensável ao aprofundamento e à compreensão da ciência na sua totalidade, esta aproximação permite o confronto de dois campos tradicionalmente antagônicos, pelo menos em abordagens curriculares, valorizando um e outro (Galvão, 2006, p.40 e 41).

Compartilhamos com os argumentos presentes em Candido (1995) que afirma ser a literatura o sonho acordado das civilizações, fator indispensável de humanização que confirma o homem na sua humanidade. Por permitir que no texto estejam presentes os diferentes valores inerentes à sociedade, sejam eles considerados bons ou ruins, a literatura, por meio dos seus diferentes gêneros:

[...] tem sido um instrumento poderoso de instrução e educação, entrando nos currículos, sendo proposta a cada um como equipamento intelectual e afetivo. [...] A literatura confirma e nega, propõe e denuncia, apóia e combate, fornecendo a possibilidade de vivermos dialeticamente os problemas [...] (Candido,1995, p. 175).

Desta forma, afirmar que pode haver um ganho de humanidade ao conhecimento científico quando este é visto a partir do olhar extraído de textos literários é compreender a humanização como um processo que confirma e, porque não, resgata no homem características essenciais cada vez mais raras nos dias de hoje, como:

[...] o exercício da reflexão, a aquisição do saber, a boa disposição para com o próximo, o afinamento das emoções, a capacidade de penetrar nos problemas da vida, o senso da beleza, a percepção da complexidade do mundo e dos seres, o cultivo do humor [...] (Candido, 1995, p. 180).

Os desafios da educação são grandes e, aparentemente, parece não ser possível visualizar soluções ou alternativas definitivas. Contudo, é certo que a literatura pode contribuir muito para a formação de um cidadão contemporâneo mais humano e comprometido com a vida e o coletivo, pois "a literatura desenvolve em nós a quota de humanidade na medida em que nos torna mais compreensivos e abertos para a natureza, a sociedade, o semelhante" (Candido, 1995, p. 180).

Diante de tais perspectivas, as relações entre leitura, literatura e produção científica vêm ganhando força como uma linha de pesquisa na área de ensino de física, com a produção de propostas que visam promover a formação mais humanística (Almeida; Silva, 1998). Vários trabalhos 
apresentam como argumentos, o uso da leitura de textos de ficção científica, romances, contos ou peças de teatro como forma de humanizar o ensino de ciências nas aulas de física, por exemplo, Deyllot (2005), Ferreira (2011), Gomes (2011), Piassi (2007), Pinto (2007), Oliveira (2004) e Oliveira (2011).

A leitura de textos literários pode, então, permitir aos leitores possibilidades de vivenciarem outras vidas por meio dos personagens podendo, no caso da ciência, refletir sobre os diferentes sentidos que essa apresenta nas relações com a sociedade. Piassi (2011, p. 208) afirma que "ao levarmos a literatura para as aulas de física estamos explicitando a posição da ciência na rede maior da cultura em que ela se inscreve, evidenciando seu caráter de experiência humana individual e coletiva".

Em trabalho sobre literatura e cultura científica, Zanetic (1998, p. 13 e 14) discute a ideia do cientista com veia literária e do escritor com veia científica. Os escritores incluídos na segunda categoria são aqueles que "com menor ou maior conhecimento das grandes sínteses científicas e suas implicações, produziram obras literárias utilizando tal conhecimento tanto como fonte inspiradora do conteúdo quanto como guia metodológico/filosófico". Zanetic (2006) dá alguns exemplos de escritores com veia cientifica, citando: Edgar Allan Poe, Gustave Flaubert, Emile Zola, Fiodor Dostoiévski, Julio Verne, Herbert G. Wells, Monteiro Lobato, Bertolt Brecht, Arthur Koestler, Primo Levi e Italo Calvino.

Os escritores se embrenham na aventura científica porque a "ciência fascina, e isso obviamente tanto mais porque ela parece misteriosa, e também porque ela modifica, por suas aplicações práticas, e a uma velocidade sempre crescente, as circunstâncias que envolvem o homem" (Vierne, 1994, p. 81). Desta forma, as obras de escritores com veia científica incorporam características que podem ser identificadas na narrativa dos diferentes gêneros literários, sendo comum a presença de aspectos que enfatizam a formação humana, o potencial de atribuir sentidos diversos à ciência nos diferentes contextos e a possibilidade de explorar as relações entre ciência, tecnologia e sociedade.

Galvão (2006), por exemplo, problematiza o potencial dos livros, Cem Anos de Solidão (realismo fantástico) de Gabriel García Márquez e Rios de Púrpura (romance policial) de Jean-Christophe Grangé, exemplificando formas distintas dos escritores incorporarem a ciência no texto literário. No primeiro, temos a presença da ciência e tecnologia, abordadas por meio da estória da saga de uma família que perpassa por várias gerações, permitindo "olhar" a evolução da ciência e sua relação com a sociedade ao longo do tempo. No segundo, a ciência está representada na ação de cientistas que utilizam seus conhecimentos e a tecnologia para ajudar detetives a desvendarem crimes. Sobre os dois livros mencionados, a autora tece os seguintes comentários:
E todo texto, numa narrativa rica, estabelece esta ligação fortíssima com a ciência e a tecnologia e com as possibilidades de viajar para além do espaço de nascença, numa dimensão que só a procura incessante do conhecimento consegue dar. Mas não são só os objetos tecnológicos que estão presentes neste romance, é a própria história da ciência que está em evidência e as implicações sociais das descobertas científicas. As possibilidades variadas de exploração de significados tornam este romance muito rico, por exemplo, numa situação escolar (Galvão, 2006, p. 37).

[...] Compreender fenômenos da poluição e da evolução da composição da água são indispensáveis para deslindar os assassínios que vão acontecendo, do mesmo modo que só é perceptível toda a maquinação que leva à evolução diferenciada daquelas populações, se os mecanismos básicos de genética e de hereditariedade fizerem parte do conhecimento do leitor. $\mathrm{O}$ autor explica de um modo simples todos os fenômenos, recorrendo a cientistas que vão sendo os auxiliares dos detetives. Trata-se de uma obra admirável que intercruza o conhecimento científico e o literário de uma forma extremamente cativante (Galvão, 2006, p. 37 e 38).

Assim, a problematização do ensino de ciências por meio da relação entre a ciência e a literatura, pode sensibilizar os educadores na escolha de temas que provoquem no estudante, a vontade de buscar o conhecimento a partir da pluralidade de relações possíveis que a literatura e a ciência juntas oferecem. Um romance pode inserir o aluno no contexto social, político, ético e cultural de determinada época e, por meio da ficção, permitir que o imaginário construa imagens da ciência como produto das ideias e das ações do homem.

Salomão (2005) afirma que uma das contribuições que o texto literário pode trazer, tanto para o professor quanto para o aluno, é que "as histórias convidam a saber", como percebeu no seu estudo sobre o uso da peça Lições de Botânica de Machado de Assis em aulas de ciências do Ensino Fundamental. A autora argumenta em suas considerações finais que, ao trabalhar-se com o texto literário em aulas de ciências "há que se investir nas pistas encontradas no texto literário e nas relações diferenciadas que consegue traçar com a realidade, frestas abertas para a pesquisa e a aprendizagem de alunos e professores" (Salomão, 2005, p. 220).

No cenário pertinente ao ensino da química, é possível destacar alguns trabalhos que abordam a temática da leitura de textos literários. Porto (2000), por exemplo, discute sobre o potencial de relações interdisciplinares por meio da problematização do poema Psicologia de um Vencido de Augusto dos Anjos. Em outra perspectiva, Porto et al. (2007) 
discutem a utilização do capítulo Potássio, do livro A Tabela Periódica de Primo Levi, um escritor com veia científica, como tema inicial para abordar conceitos químicos com alunos da graduação na perspectiva de provocar os estudantes na busca de respostas aos problemas apresentados no texto.

Gonçalves (2014) também estudou o livro A Tabela Periódica, com a intenção de destacar as possibilidades de abordagens experimentais na formação de professores com o intuito de mostrar aos futuros professores de química, "maneiras de colaborar para um processo interdisciplinar na educação básica" (Gonçalves, 2014, p. 84).

Nessa perspectiva, o pesquisador problematiza o potencial do livro para discutir diferentes aspectos relacionados à experimentação no contexto de disciplinas da área de ensino de química, tais como: o papel do erro nas atividades experimentais; preocupação com a integridade física nas atividades; a experimentação em situações problemas e questões epistemológicas sobre a experimentação e a ciência (Gonçalves, 2014). Diante de tais características, o livro pode "ser uma forma de fomentar a desejável interdisciplinaridade na formação inicial de professores de química [...] enriquecida com o apoio de outras componentes curriculares como as de história das ciências" (Gonçalves, 2014, p. 98).

Pinto Neto (2001) investigou as representações de ciência e fazer ciência em romances produzidos no Brasil entre o final do século XIX e início do século XX. Assim como, discutiu o potencial de dois escritores com veia científica por meio dos trabalhos: Júlio Verne: o propagandista das ciências (Pinto Neto, 2004) e A Química segundo Primo Levi (Pinto Neto, 2008).

No trabalho sobre Primo Levi, o pesquisador levanta algumas questões interessantes a respeito da inserção da literatura na formação de professores de química, por exemplo: “- O que os futuros professores de química devem ler? Ou para os espíritos mais pragmáticos, uma outra que é mais fácil de ser respondida: Quais são as obras e autores que fizeram da química seu tema de fabulação?" (Pinto Neto, 2008, p. 02).

Vários são os escritores com veia científica que inserem a química no enredo de suas estórias, Primo Levi é um exemplo, uma vez que "sua obra pode ser lida como uma profunda reflexão sobre o significado da 'humanidade' e, por outro lado, sobre os processos de "desumanização" (Pinto Neto, 2008, p. 04). Segundo o pesquisador, o escritor nos leva a refletir sobre as relações entre a indústria química alemã e o nazismo durante a segunda guerra mundial, sendo que para Primo Levi:

[...] a química é muito mais do que o simples aprendizado de uma disciplina ou o exercício de um ofício, é uma experiência de vida, que não pode ser separada do homem, que irá transformá-lo e, ao mesmo tempo, será moldada segundo qualidades de quem é o seu portador (Pinto Neto, 2008, p. 4).
A poesia Lágrima de Preta de Antônio Gedeão foi tema do trabalho de Silva (2011) que estudou o potencial do texto nas aulas de química na Educação Básica, assim como destacou a possibilidade de a poesia contribuir para a "formação de professores críticos, autônomos, versáteis que entendam o conhecimento científico como uma das muitas formas de conhecimento, que está presente em diversos contextos" (Silva, 2011, p. 84).

Podemos inferir que existe um consenso entre os diferentes estudos apresentados sobre a literatura e o ensino de química. Ambos os autores citados, discutem que o texto literário emerge como uma alternativa para promover a leitura na formação inicial de professores, possibilitando uma formação mais ampla do ponto de vista cultural e a oportunidade de vivenciar diferentes olhares a respeito da realidade. A aproximação entre literatura e educação pode, portanto, contribuir na formação de futuros educadores porque o texto ficcional promove uma forma de diálogo silencioso que resgata a capacidade de refletir e buscar significados para as razões de ensinar, quaisquer que sejam os conhecimentos (Brayner, 2005).

O texto literário, portanto, por meio de suas personagens pode provocar no leitor sentimentos e a vivência de situações imaginárias originadas a partir da dualidade realidade e fantasia. Desta forma, a "inserção do leitor na obra se dará, muitas vezes, através da vida das personagens. O leitor insere-se na vida do personagem, e com ele vive aventuras que o seu mundo não lhe pode proporcionar" (Pinto Neto, 2001, p.38).

A obra de Monteiro Lobato tem sido objeto de várias pesquisas, por exemplo, sobre a presença da ciência na sua produção literária, como nos trabalhos de Apóstolo Netto (1996), Camenietzki (1988), Carvalho (2002), Groto (2012), Groto e Martins (2015a; 2015b), Oliveira (2011), Pereira (2006), Santos (2011) e Scavone (1981). Na maioria dos trabalhos, destaca-se o potencial da obra para despertar as relações interdisciplinares que possibilitam discussões sobre as questões éticas, culturais, econômicas e sociais envolvidas em torno do conhecimento científico e tecnológico.

Os estudos também revelam que é possível identificar nos livros infantis de Monteiro Lobato um caráter pedagógico, por exemplo, aproximando o pensamento do escritor com diferentes pensadores da educação, como: Georges Snyders (Catinari, 2006), Anísio Teixeira e Paulo Freire (Abreu, 2004) e Jean Piaget (Macedo, 1996). Assim como, outros trabalhos sobre a relação entre Lobato com os ideais do Movimento da Escola Nova, como: Arapiraca (1996), Cardoso (2007), Nunes (2004), Santos (2008) e Valente (2004).

Diante das contribuições que o texto literário pode trazer para o ensino de química e a formação de professores, investigamos o potencial pedagógico dos livros infantis de Monteiro Lobato, buscando identificar trechos que 
evidenciam as possíveis relações entre a literatura, ciência e química na perspectiva de compreender de que forma o texto de Lobato pode promover reflexões sobre a prática docente no contexto da formação inicial de professores de química.

Neste artigo, apresentamos a análise do livro $O$ Poço do Visconde, utilizando como referencial a perspectiva pedagógica de Paulo Freire, especificamente as noções sobre o papel da curiosidade, da pergunta e do diálogo nas situações de ensino e aprendizagem presentes no livro.

\section{Paulo Freire e a curiosidade: por uma pedagogia da pergunta}

Freire $(1995,2002,2009 b)$ afirma que a curiosidade é um componente essencial no processo de construção de saberes, algo como um combustível que alimenta o ser humano de dúvidas e perguntas, permitindo que não se apague a capacidade que temos para nos espantar diante do desconhecido e sentir necessidade de buscar respostas a respeito da razão das coisas que estão ao nosso redor.

Um exemplo são as crianças na fase dos por quês e a busca incessante que apresentam sobra a razão de tudo que está ao redor delas. Ou seja, o que Freire discute como possibilidade gnosiológica que só ocorre se houver disposição à curiosidade e sem a pergunta "bem feita ou mal fundada, não importa - não haveria a atividade gnosiológica, expressão concreta de nossa possibilidade de conhecer" (Freire, 1995, p. 76).

Nesse sentido, assumindo que somos seres sociais e históricos capazes de transformar a realidade (Freire, 2009a), quer sejamos alfabetizados ou não alfabetizados; professor; empregado ou empregador; todos nós, seres do mundo e com o mundo, possuímos uma leitura que antecede a leitura da palavra. Tal compreensão é relevante, pois é na leitura do mundo que está presente a curiosidade de cada um, possível de ser provocada e cultivada ou sufocada e reprimida. Desta forma, no contexto da prática educativa não se deve separar leitura do texto e leitura do contexto, leitura do mundo e leitura da palavra, pois isso pode significar a castração da "curiosidade epistemológica" dos educandos (Freire, 1995, p. 33).

A capacidade de aprender é inerente à possibilidade de o educando ter curiosidade o suficiente para buscar o conhecimento, fruto da necessidade e/ou desejo que surge de compreender a razão das coisas e ampliar os horizontes de sentidos à leitura do mundo. Busca interminável, na qual se deve ter a consciência de que nunca se sabe tudo e, por isso, sempre será possível saber mais e melhor o que já se sabe, o que ainda não sei, assim como a possibilidade de "saber que posso produzir conhecimento ainda não existente" (Freire, 1995, p. 18).

Nesse contexto, é preciso entender a curiosidade como peça fundamental do alicerce epistemológico que estrutura a busca pelo saber na pedagogia de Paulo Freire, sendo necessário compreender as noções de curiosidade epistemológica e curiosidade ingênua ou espontânea definidas pelo autor.

A curiosidade ingênua ou espontânea é aquela que está associada ao saber que vem do senso comum, fruto da experiência acumulada com a prática e os saberes populares, ou seja, a curiosidade ingênua está relacionada ao contexto concreto, ao contrário da curiosidade epistemológica, que leva o indivíduo a buscar a razão de ser das coisas e a construção de conhecimentos sistematizados.

No ensino da química, um exemplo de situações onde não se instiga a curiosidade epistemológica pode ser ilustrado por meio de situações a respeito da experimentação destituída de problematização, como nas reações que causam explosões ou que provocam mudanças de cores vibrantes, demonstradas no laboratório, por exemplo, a reação de desidratação do açúcar com ácido sulfúrico concentrado.

A curiosidade cessa com o resultado concreto dessa experiência. A busca pela razão do fenômeno e a reflexão sistemática sobre a racionalidade do mesmo não é provocada na maioria das situações de ensino. Por isso, não são estranhas as manifestações como a do escritor Elias Canetti $(1989$, p.107) que afirmou sobrar muito pouco das aulas de química que teve na educação secundária, "além das fórmulas da água e do ácido sulfúrico [...] ficou-me somente um verdadeiro vácuo de conhecimento".

Algo mais significativo que esse "vácuo de conhecimento" sobraria se, no caso da desidratação do açúcar, o professor provocasse o aluno a pensar nos resultados observados, por meio de perguntas reflexivas como: Por que formou carvão se não ocorreu uma combustão ou queima do açúcar? Os mesmos resultados seriam obtidos com concentrações mais diluídas de ácido sulfúrico? E se fosse utilizado outro ácido? Muitas seriam as questões a serem levantadas de tal forma que, quanto mais fosse possível exercer criticamente a capacidade de aprender, tanto mais se poderia construir e desenvolver o que Freire chama de "curiosidade epistemológica", sem a qual não se alcança o conhecimento cabal do objeto (Freire, 2009b, p. 25).

A diferença entre as curiosidades ingênua e epistemológica está, portanto, na forma como o objeto de conhecimento é visto e tratado. A curiosidade epistemológica está relacionada ao caminho que permite afastar-se desse objeto, por meio da dúvida e do questionamento da realidade, com vistas a atingir o conhecimento científico ou um "conhecimento com maior exatidão".

A curiosidade epistemológica só será atingida se for possível problematizar o senso comum, por meio de caminhos que permitam ao educando superar a curiosidade ingênua e romper com o conhecimento do senso comum. No entanto, isso não significa desrespeitar o conhecimento do educando, ao contrário, quanto mais for possível conhecer e compreender os saberes apresentados pelos educandos, 
melhor será a possibilidade de problematizar a realidade em torno deles. O educador não pode desrespeitar a "curiosidade do educando, o seu gosto estético, a sua inquietude, a sua linguagem, mais precisamente, a sua sintaxe e sua prosódia" (Freire, 2009b, p. 59 e 60).

Na Figura 1, apresentamos uma síntese que ilustra o nosso entendimento sobre os aspectos epistemológicos que norteiam o processo de busca pelo saber a partir da pedagogia de Paulo Freire. Partimos da noção freireana de que o saber é sempre incompleto, por isso a necessidade de instigar a sua busca por meio do diálogo entre a curiosidade ingênua e a curiosidade epistemológica que, quando apresentadas na forma de situações problemas aos educandos, poderão conduzir ao conhecimento científico ou sistematizado.

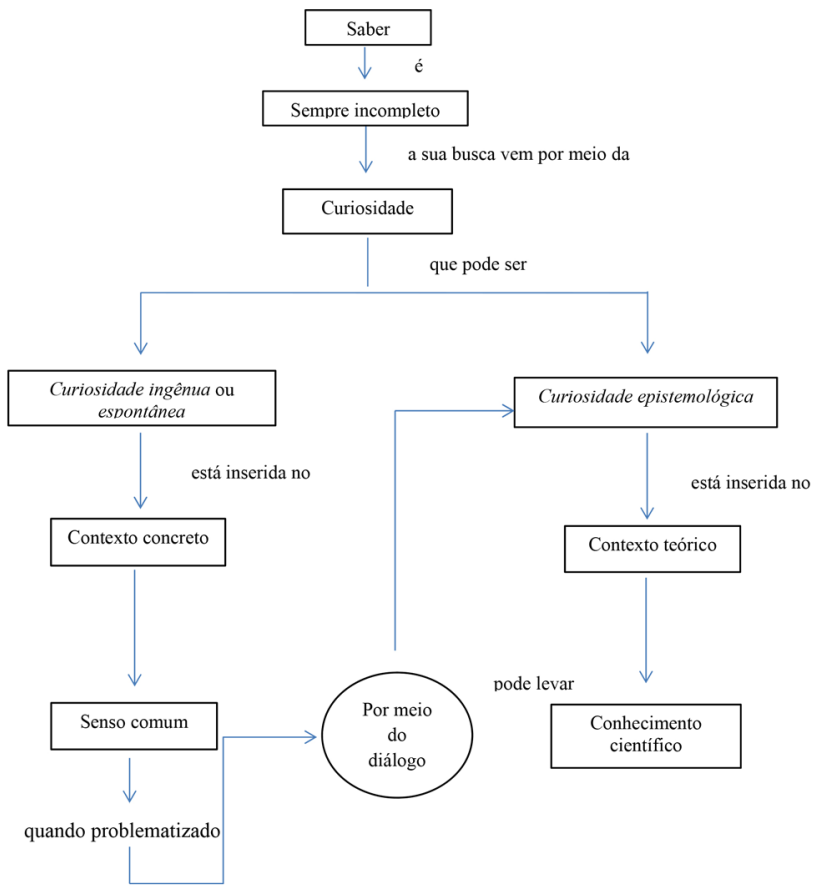

Figura 1: Representação da busca pelo saber.

Para isso ocorrer, são necessárias propostas pedagógicas que priorizem o diálogo e a construção dos conhecimentos a partir da experiência de vida que o educando possui e da leitura que esse faz do contexto ou, como afirma Freire (2009a), da leitura que o educando faz do mundo. Assim, é possível problematizar a curiosidade ingênua que pode evoluir à curiosidade epistemológica, como via necessária para olhar o contexto com um viés teórico que permita compreendê-lo e transformá-lo.

Nesse processo, a problematização é o princípio norteador de uma pedagogia da pergunta, pois é por meio dela que são promovidos questionamentos sobre determinado aspecto da realidade e a curiosidade que instiga o educando. Cabe ressaltar que pergunta e curiosidade estão entrelaçadas e são fundamentais para que o educando busque o conhecimento, uma vez que "todo o conhecimento começa pela pergunta" chamada por Freire de "curiosidade. Mas a curiosidade é uma pergunta!" (Freire; Faundez, 2002, p. 46).

Desta forma, a busca pelo saber se inicia com a possibilidade de o educando fazer "as perguntas que nos estimulam e estimulam a sociedade. Perguntas essenciais, que partam da cotidianeidade, pois é nela onde estão as perguntas" (Freire; Faundez, 2002, p. 48). Em outras palavras, a problematização não é somente a elaboração de perguntas a respeito de determinado assunto, mas é a sistematização de uma reflexão profunda entre educador, educando sobre uma situação problema, com o objetivo de identificar quais conhecimentos se fazem necessários para buscar soluções.

De acordo com Ricardo (2003), o problema não ocorre simplesmente por não sabermos respostas, pois não saber algo é natural. O problema só se torna significativo quando não sabemos respostas sobre algo que necessitamos ou queremos saber.

O posicionamento problematizador que temos discutido será um dos pilares na análise do livro $O$ Poço do Visconde e na identificação do potencial pedagógico do livro para o ensino de química.

\section{Um pouco sobre o Visconde e O Poço do Visconde}

O Visconde é um personagem que em todas as suas ações está diretamente ligado à ciência, desde o seu nascimento apresenta fascínio pelos livros e os estudos. Em várias situações, ao longo de toda a obra infantil, apresenta-se como uma espécie de caricatura do sábio livresco, ou seja, aquele intelectual que tem um saber erudito marcado pela memorização de fatos, nomes e outras "coisas" científicas e sem aparente conexão com a realidade.

Como afirmam vários estudiosos da obra de Monteiro Lobato, o Visconde é a personificação do cientista e da ciência na obra infantil do escritor. Nasce em Reinações de Narizinho e, juntamente com Emília, protagoniza as aventuras de A Reforma da Natureza e A Chave do Tamanho; é o responsável pelos estudos geológicos que permitem a descoberta de poços de petróleo em $O$ Poço do Visconde. Em Aritmética da Emília, é o responsável por receber o "País-da-Matemática" no circo montado no sítio. É quase impossível discutir sobre ciência na obra de Monteiro Lobato sem refletir sobre a personagem Visconde de Sabugosa - o sabugo científico.

O Visconde é o cientista capaz de promover grandes invenções. Sempre compenetrado em seus estudos, não tem a astúcia da Emília, a ousadia de Narizinho e Pedrinho ou a sabedoria "universal" de Dona Benta, mas está sempre disposto a encarar os desafios do conhecimento e é o exemplo de um dedicado estudioso das ciências.

De acordo com Lajolo e Zilberman (1999), sempre é preciso considerar o momento histórico e as questões 
culturais, econômicas e sociais de determinada época para discutir textos literários que estão diretamente relacionados a esses contextos, com a literatura infantil isso não deve ser diferente. Por isso, é importante considerar que na obra de Monteiro Lobato é marcante a presença do positivismo enquanto corrente filosófica em seus livros, refletida no ideário pedagógico, político ou científico do escritor.

Ser positivista no Brasil, no período de 1900 a 1930, segundo Gois Junior (2003), significa ser, sobretudo, um cientificista e acreditar na ciência, não é por menos que a crença no progresso e no poder da ciência como forma de dominar e transformar a natureza sempre estiveram presentes na obra infantil e adulta do escritor. Em texto publicado no jornal O Estado de São Paulo, no qual Monteiro Lobato fala da sua crise mental a respeito das influências das diferentes correntes filosóficas em seu pensamento, o escritor deixa clara a importância que dava ao raciocínio científico:

[...] A ciência positiva "prova" e quando há provas, que lugar subsiste para a dúvida? Acostumei-me a aceitar as conclusões da ciência, dispensando-me de experiências pessoais diante da experiência coletiva e convergente dos sábios (Lobato, 1961, p. $222-224)$.

Diante da necessidade de considerar o contexto histórico onde estão inseridas as estórias e a produção literária do escritor, ressaltamos a importância do texto literário como forma de problematizar questões relacionadas à natureza do conhecimento científico e as visões de ciências vinculadas aos personagens, como argumentam Groto e Martins (2015b, p. 394): os textos "poderiam ser utilizados na problematização e na reflexão sobre essas mesmas visões de ciência que veiculam, contribuindo para a construção de visões mais adequadas, menos distorcidas e empobrecidas da atividade científica".

O Poço do Visconde pode ser considerado um exemplo de abordagem que tem como projeto principal a exploração de petróleo no Sítio do Picapau Amarelo. O tema envolve conhecimentos de geologia, química, física, biologia, além das questões econômicas e políticas pertinentes ao contexto no qual o livro foi escrito, configurando-se em um exemplo interessante de proposta interdisciplinar de ensino.

Monteiro Lobato parece incorporar nessa obra os princípios apontados por Teixeira (2007), ou seja, as crianças vão aprendendo conforme a necessidade aparece e o escritor consegue tornar viável o acesso das crianças a assuntos complexos, respeitando a capacidade cognitiva delas, mas sem vulgarizar o conhecimento científico. O livro é o volume dez da série infantil de Monteiro Lobato, publicado em 1937 (Chiaradia, 2008).

Como afirma Bosi (1982), Monteiro Lobato no campo da literatura infantil é considerado um escritor "absolutamente revolucionário" e demonstra toda a sua modernidade, inclusive no que se refere aos aspectos educacionais e científicos. O escritor não subestima a inteligência das crianças e, embora as estórias tenham sido escritas para um público infantil, os assuntos abordados são complexos e incluem temáticas antes não consideradas pertinentes a esse tipo de público, tais como: política, economia, filosofia e ciência, todas tratadas com seriedade.

Luciana S. de Oliveira (2011) fez um estudo sobre a perspectiva científica de Monteiro Lobato no livro $O$ Poço do Visconde, utilizando referências da História da Ciência e, como parte dos resultados, revela que muitos trabalhos acerca do escritor não fazem a devida contextualização da obra como parâmetro de análise. Como consequência, é comum surgirem manifestações ingênuas e equivocadas a respeito de Lobato, como por exemplo, considerá-lo um "sonhador de forma pejorativa".

Ora, Monteiro Lobato defendia a necessidade de apresentar às crianças fatos concretos, sem que houvesse a subestimação da condição plena de seu entendimento. Por isso, pode-se afirmar que ele não teve a pretensão de substituir uma obra científica por um texto literário, tampouco diminuir a importância do aprofundamento científico. Pelo contrário, demonstrou que ambos podem caminhar lado a lado; a Literatura como alimento para o interesse científico, um mapeamento para aqueles que almejem especializar-se em ciência, ou ao menos valorizá-la devidamente (Oliveira, 2011, p. 125- 126).

Segundo Santos (2008), a visão sobre as benfeitorias e transformações que o progresso poderia trazer para a sociedade brasileira está exemplificada no livro $O$ Poço do Visconde, nas mudanças que ocorrem no sítio e no seu entorno. A ciência alcança a sua plenitude em $O$ Poço do Visconde e o escritor evidencia sua defesa de uma educação científica mais significativa e a possibilidade de a criança ser ativa no processo de reconstrução de um novo Brasil, demonstrando que uma ciência aplicada "poderia servir para seus pequenos leitores: por um lado era uma educação científica mais eficaz e próxima destes e, por outro, já sugeria o papel para estes mesmos leitores na construção do Brasil futuro" (Santos, 2008, p. 59).

Cabe destacar que a dimensão do problema no livro $O$ Poço do Visconde não está apenas em como ensinar, mas no que ensinar, que é escolhido a partir das necessidades que surgem da problemática em torno da possibilidade de perfurar e explorar o petróleo no sítio, discutidas coletivamente entre as personagens. A temática também incorpora as contradições inerentes a um tema que apresenta interações diretas com as questões sociais, econômicas, políticas e culturais relatadas no livro. 


\section{O Visconde, as crianças e a exploração do poço de petróleo: problematizando $o$ ensino}

Dona Benta sempre recebia os jornais no sítio e procurava manter-se informada a respeito do que ocorria no Brasil e no mundo. Pedrinho adquiriu o mesmo hábito da avó e logo passou a acompanhar as notícias, lendo os jornais todos os dias, à moda americana, como dizia Narizinho, "de sentar-se com os pés na cara da gente". O menino andava incomodado com as frequentes notícias sobre a procura de petróleo no Brasil e, como havia aprendido com Dona Benta que petróleo era sinônimo de progresso e garantia de riquezas para uma nação, começou a pensar seriamente sobre o assunto: “- Bolas! Todos os dias os jornais falam em petróleo e nada do petróleo aparecer. Estou vendo que se nós aqui no sítio não resolvermos o problema, o Brasil ficará toda a vida sem petróleo" (Lobato, 1957, p. 2).

O problema central do livro se situa justamente nesse contexto. Pedrinho acredita que existe petróleo no Brasil e o mesmo pode ser explorado no Sítio do Picapau Amarelo. O menino analisa a situação e conclui que "com um sábio da marca do Visconde para nos guiar, com as ideias da Emília e com uma força bruta como a do Quindim, é bem provável que possamos abrir no pasto um formidável poço de petróleo. Por que não?" (Lobato, 1957, p. 2 e 4).

Todavia, como saber se existe petróleo no sítio, se é possível extraí-lo e como fazer tal trabalho? Foi, então, que o menino se lembrou dos boatos da Emília sobre o Visconde, que andava estudando um tratado de geologia encontrado na biblioteca de Dona Benta e, de tanto estudar tinha ficado "com um permanente sorriso de superioridade nos lábios sorriso de dó da ignorância dos outros. Ele já entende de terra 'mais que tatu', dizia a boneca" (Lobato, 1957, p. 2). Assim, o sábio sabugo foi convidado pelo menino para uma consultoria técnica:

- O amigo Visconde já deve estar afiadíssimo em geologia, de tanto que lê esse tratado. Pode, portanto, dar parecer num problema que me preocupa. Acha que poderemos tirar petróleo aqui no sítio?

O Visconde respondeu, depois de cofiar as palhinhas do pescoço:

- É possível sim. Com base nos meus estudos, estamos em terreno francamente oleífero (Lobato, 1957, p. 4).

O Visconde aceitou o desafio de conduzir as investigações geológicas no sítio, mas avisou sobre a necessidade de "abrir um curso de geologia. Sem que todos saibam alguma coisa da história da terra, não podemos pensar em poço. Como já li esta Geologia inteira, proponho-me a ser o professor" (Lobato, 1957, p. 5). Assim foi feito, Pedrinho "arrumou a sala como um anfiteatro de escola superior" e o Visconde começou suas aulas de geologia.

Em $O$ Poço do Visconde, nosso personagem principal, com o uso de sua sabedoria científica, identifica os possíveis locais de extração, disserta sobre as alternativas de uso e refino do petróleo e nunca deixa de explicar o significado de cada passo dado na aventura. Com o seu conhecimento científico, abre as portas para grandes transformações que ocorrem no sítio e em suas redondezas, promovendo a riqueza e a melhoria das condições de vida dos habitantes que ali viviam.

As aulas são conduzidas a partir da curiosidade da turma do sítio em aprender tudo sobre o petróleo. Pedrinho e Narizinho não se cansam de fazer perguntas e a cada resposta do sabugo professor querem saber mais e mais. O Visconde, por sua vez, é um "poço" de sabedoria e não se cansa de falar sobre geologia.

As crianças dão o ritmo das aulas e problematizam a temática principalmente por meio de dúvidas e perguntas. A cada resposta, a curiosidade das crianças aumenta e elas parecem nunca satisfeitas. Como consequência, é comum Pedrinho e Narizinho utilizarem interrogações do tipo: "E por que motivo? Como é isso? Como sabe disso? Mas como? O que fazer? De que modo?" As perguntas denotam um querer saber mais das crianças, com ênfase no desenvolvimento do raciocínio e reflexão sobre o conhecimento apresentado que ilustram a constante tentativa de problematização dos saberes em discussão, por exemplo:

- Que quer dizer ígnea? Indagou Pedrinho. (Lobato, 1957, p. 11)

- E que é sedimentar?

-E as tais rochas orgânicas? - E o tal metamorfismo? - quis saber a menina. (Lobato, 1957, p. 16)

- De que modo a rocha fala das plantas e dos animais? - quis saber Narizinho. (Lobato, 1957, p. 22)

- Que quer dizer matéria orgânica? (Lobato, 1957, p. 25)

- Quer dizer que o petróleo se forma nesse lodo enterrado? (Lobato, 1957, p. 27)

- E que se faz para prevenir que o jorro de petróleo escangalhe com tudo? (Lobato, 1957, p. 54).

A intenção de Lobato era que as crianças fossem protagonistas ativas no processo de construção dos conhecimentos, como pode ser ilustrado na fala da Emília, ao expressar a insatisfação por não entender uma explicação do Visconde sobre protoplasma e a origem da vida: “- Pro-to-plas-ma repetiu Emília. Explique o que é. Eu não finjo que sei as coisas" (Lobato, 1975, p. 23 - grifo nosso).

O Visconde não problematiza, mas conduz as aulas conforme a curiosidade das crianças que parecem ter adquirido a maturidade e o costume de perguntar. Monteiro Lobato, 
por meio da Emília, do Pedrinho e da Narizinho, ensinava as crianças leitoras a questionarem o mundo dos adultos e a dizerem: Por quê? Talvez, conduzindo as crianças a uma situação semelhante ao que Freire (1983, p. 87) diz em Pedagogia do Oprimido, “Nenhuma 'ordem' opressora suportaria que os oprimidos todos passassem a dizer: Por quê?".

O entendimento sobre o petróleo perpassa por várias áreas do conhecimento, exigindo que o tema seja abordado por meio de uma perspectiva interdisciplinar. Conforme surge a necessidade, as áreas específicas são introduzidas, por exemplo, no meio da discussão sobre os sedimentos marinhos e a formação do petróleo, o Visconde afirma que os cemitérios de matéria orgânica "têm que ficar incubados, como ovos na incubadeira, sob tais e tais condições; do contrário não saem os pintos do petróleo" (Lobato, 1957, p. 32). Em seguida, Pedrinho pergunta, mas “- Que condições são essas?".

Nesse momento é necessário refletir sobre o oxigênio e as interações que esse faz com diferentes materiais. Monteiro Lobato mistura o conhecimento científico com expressões que são significativas para as crianças, conforme ilustramos a seguir:

- Uma delas é ficarem isolados das águas. Esse isolamente livra a matéria orgânica de ser devorada por certos seres viventes, os urubuzinhos do mundo pequeno. E também livra da forme insaciável do maior urubu que existe na Natureza, o tal Senhor Oxigênio. Este freguês tem um apetite de cabra. Come tudo quanto encontra, isto é, oxida tudo quanto encontra, como dizem os químicos. O oxigênio existe na água e no ar; por isso a matéria orgânica que cai na água, ou está exposta ao ar, estraga-se depressa, desaparece, oxida-se - é devorada, em suma, pelo terrível urubu.

- Ah! -exclamou Pedrinho. Então é por esse motivo que não se forma petróleo na matéria orgânica de cima da terra. Está exposta ao ar, entregue à fúria do oxigênio...

[...]

- Também com a matéria orgânica o oxigênio faz a mesma coisa. Oxida-a, enferruja-a, combina-se com o carbono que há nela e solta o hidrogênio. Mas quanto a matéria orgânica fica enterrada e portanto fora de contacto com o oxigênio da água ou do ar, podem acontecer coisas diferentes - como essa de formar-se o petróleo Lobato (1957, p. 32 - 33).

O escritor procura tornar significativos os conceitos que introduz no diálogo com as personagens, como faz na discussão sobre o papel do oxigênio na formação do petróleo. É importante considerar que os conhecimentos apresentados precisam de uma revisão, pois o livro foi escrito em 1937, assim como a licença literária que o escritor possui para escrever sem a exatidão que exigiria um livro específico de ciências, mas com a preocupação de que é preciso pensar nos conceitos, uma vez que Lobato toma o cuidado de destacar as palavras oxida e oxida-se.

Nas discussões referentes à formação do petróleo e à constituição da matéria orgânica que dá origem ao mesmo, as crianças chegam a "sufocar" o sabugo de tantas perguntas. O Visconde não explica somente como o petróleo é formado, mas insere informações a respeito das jazidas ao redor do mundo, por exemplo, "Aqui na América do Sul temos os campos petrolíferos de Comodoro Rivadávia, na Argentina, rente ao gôlfo de S. Jorge" (Lobato, 1957, p. 35). A curiosidade não é mais ingênua, Pedrinho quer saber mais e mais, como expressa na pergunta que faz após o Visconde explicar como os argentinos faziam para procurarem petróleo: "- Está tudo bem, Visconde - disse Pedrinho. Mas eu queria saber como a tal matéria orgânica vira petróleo" (Lobato, 1957, p. 36).

O Visconde tomava fôlego, explicava e mais perguntas apareciam: "- Mas eu quero saber como se faz a passagem do tal lôdo de matérias orgânicas para petróleo, reclamou Narizinho" (Lobato, 1957, p. 37). As explicações continuam: “- No laboratório os químicos sabem fazer essa passagem. Já contei a experiência de Engler. Calor de 400 graus e pressão de 20 a 25 atmosferas" (Lobato, 1957, p. 37).

As crianças do sítio não ficam caladas quando não compreendem algo ou ouvem o Visconde falar sobre conceitos ainda não discutidos, como é possível observar na reação que apresentam depois de aparecer o termo atmosfera: “Espere, Visconde. Vossa Excelência esqueceu de explicar o que é UMA atmosfera. Só falou na atmosfera em geral" (Lobato, 1957, p. 37).

Foi necessário o Visconde alertar as crianças que não seria possível aprofundar mais o assunto: "- Muito bem. Creio que quanto à formação do petróleo basta ficarmos nisto. Meu curso não é para formar especialistas, sim para dar uma ideia geral da coisa" (Lobato, 1957, p. 38). O sabugo professor não se cansa de responder, mas ao alertar que o seu curso não era "para formar especialistas" e de que nada valeria continuar falando de coisas que não seriam inteligíveis às crianças, demonstra a preocupação de Monteiro Lobato com o nível de entendimento das mesmas.

O livro mistura realidade com ficção e apresenta, por meio das personagens, o olhar de Monteiro Lobato. De acordo com Oliveira (2011, p. 124), O Poço do Visconde "surgiu no período de efervescência de sua luta pelo petróleo - considerado por Lobato como a mola propulsora do desenvolvimento norte americano. Pode-se considerar a obra como uma (re) construção pseudo-fictícia da realidade brasileira". Por isso, é comum o Visconde inserir em suas aulas comentários sobre questões econômicas e políticas 
que eram pertinentes ao contexto real do período no qual foi escrito o livro, como no trecho em que Narizinho pergunta “- E por que o Brasil também não produz milhões e milhões de barris? Será que não existe petróleo aqui?” (Lobato, 1957, p. 51). A resposta expressa a opinião predominante de Monteiro Lobato na campanha pelo petróleo:

- Não existem perfurações, isso sim. Petróleo o Brasil tem para abastecer o mundo inteiro durante séculos. Há sinais de petróleo por toda parte - em Alagoas, no Maranhão em toda a costa nordestina, no Amazonas, no Pará, em São Paulo, no Paraná, em Santa Catarina, no Rio Grande, em Mato Grosso, em Goiás. A superfície de todos esses estados está cheia dos mesmos indícios de petróleo que levaram as repúblicas vizinhas a perfurar e a tirá-lo aos milhões de barris. Os mesmíssimos sinais...

- Então por que não se perfura no Brasil?

- Porque as companhias estrangeiras que nos vendem petróleo não têm interesse nisso. E como não têm interesse nisso foram convencendo o brasileiro de que aqui, neste enorme território, não havia petróleo. E os brasileiros bobamente se deixaram convencer... (Lobato, 1957, p. 51).

O mesmo ocorreu quando o Visconde começou a falar da produção de petróleo, das reservas e da capacidade de extração diária em barris de petróleo. Ele não deixou de expressar suas esperanças em relação ao Brasil e nas possibilidades de transformações sociais decorrentes da riqueza do petróleo:

- No dia em que tal acontecer e o Brasil passar de comprador a vendedor de petróleo, então deixaremos de ver essa coisa tristíssima de hoje - milhões de brasileiros descalços, analfabetos, andrajosos - na miséria. O Brasil tem todos os elementos para tornar-se um país riquíssimo - mas riquíssimo de verdade, e não, como hoje, apenas rico de "possibilidades" ou de "garganta".

- Bravos, Visconde! - exclamou Dona Benta. Nem parece que é um sabuguinho que está falando.

- Pudera! - gritou Emília. Num país onde até os ministros não pensam em petróleo, ou quando falam nele é para negar, só mesmo dando a palavra a um sabugo. Viva o Senhor Visconde do Poço Fundo! (Lobato, 1957, p. 62).

A abordagem científica apresentada no livro está intrinsecamente relacionada ao contexto social e político da estória. Trata-se de um dos exemplos presentes no livro que ilustra o texto literário como forma de provocar o leitor a refletir sobre aspectos pertinentes a uma determinada realidade. No caso específico do livro, uma realidade não tão distante, uma vez que na década de 1930 Monteiro Lobato trabalhava incansavelmente na busca de mostrar que existia petróleo no Brasil, em outras palavras, era um assunto que fazia parte do contexto histórico.

Ao mesmo tempo, como já mencionamos, é uma ficção que apresenta um futuro ainda por vir, na medida em que as descobertas do sítio e as transformações sociais, econômicas e culturais decorrentes do petróleo não existiam de fato. Nesse sentido, o livro permite refletir sobre o contexto histórico, o papel da ciência e tecnologia na sociedade e problematizar a visão de ciência predominante nos tempos de Monteiro Lobato.

O Visconde não tem o senso aplicativo da ciência aguçado, são as crianças que precisam alertar o sábio geológico sobre a necessidade de aplicação dos conhecimentos. Essa etapa se inicia depois que Pedrinho e as outras personagens chegam à conclusão que já seria hora de aplicar aquilo que tinham aprendido e, como o Visconde era um sábio teórico que não se cansava de aprofundar seus conhecimentos científicos, foi necessária uma intervenção do menino:

- O coitado do Brasil cansado de esperar petróleo e este cacetíssimo Visconde a nos injetar noites e noites de ciência! Não quero mais. Chegou o momento de começarmos o poço.

- Mas, como, Pedrinho, se ainda quase nada sabemos de geologia? - objetou a menina.

- Muito bem. Vamos começar o trabalho e o Visconde nos vai ensinando. Lições ao ar livre - fazendo. É fazendo que o homem aprende, não é lendo, nem ouvindo discursos. Eu quero ciência aplicada... (Lobato, 1957, p. 72 - grifo nosso).

Pedrinho é o líder da turma e, logo que o Visconde chega para o início das aulas, o menino avisa: "- Escute, senhor geólogo - disse Pedrinho. Basta de aulas. Fizemos greve. Queremos começar o poço já, já, está ouvindo?" (Lobato, 1957, p. 73). O Visconde arregala os olhos e argumenta que ainda não tinham adquirido uma boa base de conhecimentos geológicos, mas o menino não volta atrás e sugere uma solução metodológica ao Visconde: “- Damos começo ao trabalho e V. Excelência nos vai ensinando pelo caminho, à proporção que os problemas aparecerem" (Lobato, 1957, p. 73).

A ideia de ensinar por meio da necessidade em solucionar problemas que surgem no trabalho de campo, ou seja, quando o Visconde e as crianças saem da "sala de aula" e vão observar e analisar as terras do sítio, deixa evidente a concepção problematizadora do ensino presente no livro, possibilitando discutir com licenciandos em Química, os significados a respeito dessa concepção por meio do texto literário.

Cabe ressaltar que não queremos dizer que o texto literário substitui a leitura de artigos que subsidiam as dimensões 
teóricas em torno da concepção problematizadora de ensino, mas, possibilita que essa seja discutida a partir da leitura do livro ao apresentar situações de ensino vivenciadas pelas crianças do sítio. Principalmente porque existem concepções teóricas distintas a respeito do papel do problema no ensino de ciências como, por exemplo, as que apresentam Solino e Gehlen (2015) sobre a Abordagem Temática Freireana e o Ensino de Ciências por Investigação (ENCI).

Os problemas aparecem rapidamente, assim que saem para observação e estudo geológico do pasto. Pedrinho logo fica incomodado, pois "só via capins e capões de mato. Que fazer? Quem não sabe é o mesmo que ser cego. Pedrinho geólogo, sentiu-se totalmente cego" (Lobato, 1957, p. 73). A solução foi recorrer ao professor Visconde e indagá-lo sobre quais seriam os passos que deveriam tomar. O sábio sabugo explica que seria necessário investigar detalhadamente a formação rochosa do local para descobrir se o sítio estaria em cima de um anticlinal, condição esta que indicaria a existência de petróleo.

O desânimo de Pedrinho aumentava, pois novos problemas surgiam: "- Mas como estudar rochas com este raio do capim gordura a esconder a terra inteira?" (Lobato, 1957, p. 74). As perguntas não são ingênuas, mas expressam o que Freire (1995) chama de curiosidade epistemológica, uma vez que Pedrinho quer saber quais conhecimentos precisa compreender para conseguir alcançar o "sorriso geológico" do Visconde.

No alto da sua sabedoria, o Visconde ia ensinando os segredos da geologia, explicou que seria necessário encontrar barrancos, por isso conduziu as crianças para uma "barreira" existente no sítio. Mais uma vez, as crianças se espantaram. Ao avistarem o barranco o Visconde abriu um sorriso, mas como sorrir diante de um "barranco feio como todos os mais?".

\section{Emília.}

- Que gosto é esse, Visconde? - perguntou

- Ah, o sorriso que tenho nos lábios é um sorriso geológico - o sorriso de quem sabe, olha, vê e compreende. Este barranco é para mim um livro aberto, uma página da história da terra na qual leio mil coisas interessantíssimas (Lobato, 1957, p. 75-76).

O Visconde conduzia as aulas práticas, ensinando o raciocínio científico às crianças. Ele dizia que era importante observar, analisar, comparar e fazer deduções a respeito dos dados que iam acumulando ao longo do caminho. Por exemplo, logo que terminaram os estudos sobre o barranco, ele disse:

- Muito bem. Temos agora de examinar aquele corte da estrada que vai para a fazenda do Coronel Teodorico.
- Para quê?

- Para ver se as camadas de lá têm correspondência com estas. Se tiverem, poderemos tirar algumas deduções interessantes (Lobato, 1957, p. 82).

As conclusões foram animadoras e confirmaram as hipóteses iniciais do Visconde:

- Exatamente o que eu esperei! - disse ele ao examinar o corte. As camadas que estudamos no barranco têm sua continuação aqui. Cá está a camada de arenito, e a de conglomerado, e a de argila, com a única diferença da direção. No barranco as camadas subiam; aqui descem. Isto prova o que imaginei: estamos em cima dum anticlinal já em grande parte destruído pela erosão (Lobato, 1957, p. 83).

As aulas surtiam efeito e as crianças aprendiam geologia e começavam a compreender os motivos científicos que levaram o Visconde a sorrir. Tanto que, depois de realizarem os estudos geológicos das terras do sítio e encontrarem o local onde deveria haver petróleo, Pedrinho não se conteve e disse:

- Que engraçado! - exclamou Pedrinho. Agora compreendo o riso do Visconde depois que deu para estudar geologia. Como tudo se esclarece! Como fica interessante! Aquele barranco e este corte nunca me fizeram vir à cabeça a menor ideia. Agora já me falam, dizem coisas, contam pedaços da vida da terra. Que engraçado!... (Lobato, 1957, p. 83 e 84).

Cada vez mais as crianças sabiam sobre o petróleo, mas também descobriam que podiam saber mais sobre o tema, caso fossem instigadas suas curiosidades. As dúvidas já não eram tão simples e surgiam baseadas naquilo que tinham aprendido, como demonstrado na preocupação de Pedrinho:

- Uma coisa anda me preocupando, Visconde - disse ele. Estou vendo que os tais estudos geológicos só são possíveis quando há muitos barrancos e buracões. E quando não há nada disso? Quando o terreno é todo uma planície imensa, recoberta de vegetação?

- Bom, aí o geólogo não pode ver nada e portanto não pode tirar conclusões. Tem de "pedir água."

- A quem?

- À geofísica.

- Que é isso?

- Geofísica é a ciência de ver, apalpar, medir as rochas que estão lá no fundo.

- Ver, como, se estão lá no fundo?

- Ver é um modo de dizer. Em vez de ver eu devia ter dito adivinhar. A geofísica consiste na aplicação 
de uns tantos princípios da física, por meio dos quais os sábios adivinham o que não podem ver, nem apalpar. Espécie de raios $\mathrm{X}$ do fundo da terra [...] (Lobato, 1957, p. 87).

Depois que "tiveram de ver no chão se realmente existiam todas as condições favoráveis para a existência do petróleo, o sabuguinho científico começou a mostrar exigências excessivas" (Lobato, 1957, p. 97). Aos poucos, o Visconde foi se entusiasmando com os estudos teóricos sobre geologia. As crianças não perderam tempo e convocaram nova greve, com medo de ficarem presas às teorias sem previsão de aplicação dos conhecimentos científicos.

- [...] Porque nesta toadinha do Visconde ficamos toda a vida a estudar coisas dos livros e nada de perfuração. Nosso Visconde é livresco demais. Temos que declarar greve. Topam?

- Topamos - concordaram as duas, também já cansadas de ciência teórica (Lobato, 1957, p. 97).

O Visconde bem que tentou argumentar dizendo que ainda precisavam acabar o estudo geológico do terreno e fazer o estudo geofísico, mas a maioria venceu e mais uma vez convenceram o sabugo científico a tornar sua ciência útil e prática. O faz-de-conta da Emília entrou em ação: “- Faz de conta que foram feitos por uns sábios da Alemanha que mandamos vir, não acha, Pedrinho?" (Lobato, 1957, p. 98), disse a boneca sobre os estudos indicados pelo Visconde.

Após o faz de conta da Emília, Pedrinho fez as marcações de onde deveria ser feita a perfuração do poço de petróleo, baseado nas sugestões dos sábios alemães. Ao terminar, perguntou ao Visconde se estava tudo correto:

O sabugo geológico respondeu, depois de alisar as palhinhas do pescoço, que não havia nenhuma objeção a fazer.

-Então, pronto! - gritou Pedrinho. Hurra! Hurra! Hurra! O principal está feito: marcar cientificamente o lugar exato onde abrir a perfuração. O resto é canja.

Mas apesar de ser canja, Pedrinho engasgou. Não sabia o que fazer depois da marcação do ponto certo. Teve de recorrer ao Visconde (Lobato, 1957, p. 99).

A necessidade de saber mais continua sendo a base da busca pelo conhecimento, por exemplo, após a demarcação científica do local para abrir a perfuração do poço "Pedrinho engasgou. Não sabia o que fazer depois da marcação do ponto certo. Teve de recorrer ao Visconde" (Lobato, 1957, p. 99).

O Visconde colocou em prática os seus conhecimentos, listou os equipamentos e especialistas necessários para o início dos trabalhos, obtidos por meio do eficiente faz-de-conta da Emília que tornava tudo possível. As dúvidas e as curiosidades de Pedrinho não cessavam e ele acompanhava de perto todos os procedimentos realizados por Míster Kalamazoo, demonstrando o amadurecimento conceitual que alcançava sobre o petróleo.

Quando o sistema de perfuração teve que ser trocado, o menino ficou intrigado com a broca rotativa escolhida pelo americano. O menino queria saber como a broca perfuraria as rochas, pois tinha observado que a mesma não tinha dentes ou cortes como as brocas normais. Trata-se de mais um exemplo que ilustra a curiosidade nunca satisfeita de Pedrinho, assim como a sua importância no processo de sistematizar o conhecimento científico:

Tudo arrumado, a broca rotativa desceu ao fundo do poço e foi posta em movimento. Começou a girar sobre si mesma. Um silêncio. Acabara-se o pum-pã do trépano. [...]

- Mas como desce? Como a broca perfura? pensava ele consigo. Se é um simples cano de aço, sem dentes, sem corte, sem nada, como podia corroer a rocha? Mistério. Não conseguindo por si mesmo resolver o enigma, apelou para o Visconde.

-É o seguinte - explicou o sabuguinho científico: Míster Kalamazoo, quando a broca vai começar a trabalhar, despeja no fundo do poço um punhado de aço granulado.

- Que aço granulado é esse?

- Uns carocinhos dum aço duríssimo, assim do tamanho de chumbo de caçar paca. A broca vai comprimindo esse aço granulado contra a rocha e a esfarela.

- Ah! Isso sim! - exclamou o menino com o rosto iluminado. Eu até já estava com dor de cabeça de tanto parafusar no assunto. Aço granulado, sim... (Lobato, 1957, p. 129).

O potencial do livro para promover reflexões sobre a humanidade e o resgate de valores, conforme discute Candido (1995) também está presente em $O$ Poço do Visconde. Sempre que possível, o escritor insere questões que provocam o pensar sobre valores humanos, por exemplo, a preocupação com o próximo e os problemas sociais, conforme ilustramos com o trecho em que as personagens discutem sobre as casas dos operários que trabalham na perfuração do petróleo:

- Bom. Água e lenha já temos - disse ele. Agora é preciso que você, Narizinho, se encarregue das casas e do barracão para as máquinas.

A menina também aplicou o faz-de-conta, de modo que num instante surgiu da terra um excelente barracão de madeira, com telhado de zinco, para as máquinas; e cem metros dali uma série de casas para 
operários, muito bonitas e higiênicas, tão bonitas que Pedrinho achou demais.

- Demais, não! - protestou ela. Quanto melhor acomodarmos nossos homens, melhor eles trabalham. Não concordo com o sistema de tratar os operários como se fossem pedras insensíveis. As casinhas têm tudo dentro - até geladeira e rádio... (Lobato, 1957, p. 100).

Os conhecimentos químicos sobre o petróleo tais como os que se referem à composição, ao refino e às possibilidades de uso dos produtos obtidos no processo, surgem na medida em que é possível abordá-los de tal forma que possam ser significados pelas crianças. Claro que não é a intenção do escritor ensinar com detalhes determinados processos químicos e propriedades de alguns materiais, pois seria incompatível com estágio cognitivo do leitor e das personagens. A discussão sobre os aspectos econômicos que sustentam a iniciativa de refinar o petróleo é um exemplo que pode ilustrar o tipo de abordagem que discutimos:

- Porque o petróleo bruto - disse ele - só serve para queimar. Mas se o refinarmos, obteremos uma porção de produtos de muito valor, como a benzina, a gasolina, o querosene, o supergás, o óleo combustível, o óleo lubrificante, as parafinas, as vaselinas, o asfalto, o coque de petróleo e mais numerosos produtos de menor importância. Os petróleos brutos variam muito. Uns são bastante ricos em produtos voláteis; outros não dão produtos voláteis; outros só dão produtos voláteis, como o de Montechino, na Itália, que rende 95 por cento, de gasolina e querosene.

- Noventa e cinco por cento? - admirou-se Pedrinho. Então é quase todo ele gasolina e querosene...

$[\ldots]$

- Que mina! E como se faz para refinar?

- O petróleo bruto é uma mistura de vários hidrocarbonetos diferentes, uns gasosos, como o metano que vem dissolvido nos líquidos; outros líquidos; outros sólidos, como a parafina. A refinação é o processo que separa os vários hidrocarbonetos.

- Em que consiste?

- Cada um desses hidrocarbonetos, cuja mistura forma o petróleo bruto, tem a sua temperatura própria de ebulição.

- Ebulição é fervura, não é?

- Sim. Ebulição é o ponto em que os líquidos começam a ferver e a evaporar-se. Ora, esses hidrocarbonetos do petróleo bruto fervem desde 35 até 600 graus (Lobato, 1957, p. 178 e 179).
Podemos notar que as noções sobre a constituição do petróleo e o processo necessário para promover a separação dos componentes que constituem o mesmo são apresentadas no momento em que é pertinente mostrar às crianças que o valor comercial do petróleo é maior, na medida em que seja possível comercializar os seus componentes de forma individual, por exemplo, o caso da gasolina e do querosene.

Nossa discussão sobre a presença da curiosidade como componente pedagógico e epistemológico no livro $O$ Poço do Visconde não esgotam as possibilidades de leituras a respeito da proposta pedagógica que emerge do livro. Oliveira (2011), por exemplo, dedica uma parte de sua tese a tecer discussões sobre a presença do ideário do Movimento da Escola Nova e apresenta conclusões que coincidem com a leitura que fizemos da obra. De acordo com Oliveira (2011, p. 89):

Desde a ocorrência do primeiro serão, é possível perceber a presença da liberdade estabelecida entre o professor, Visconde, e seus alunos, os moradores do sítio, para contribuir com o processo ensino-aprendizagem. Por meio dos diálogos há a abertura para questionamentos, colocações e suposições, uma atitude adversa ao modelo empregado nas escolas tradicionais.

\section{Algumas considerações}

O futuro professor de química precisa, no âmbito da sua formação, discutir aspectos relacionados à prática pedagógica, como: a compreensão de diferentes concepções de ensino e aprendizagem, o uso de metodologias de ensino compatíveis com as necessidades formativas dos alunos, a elaboração de abordagens conceituais de acordo com os níveis cognitivos dos alunos, entre outros. Normalmente, tais discussões ocorrem em disciplinas consideradas pedagógicas tais como: Prática de Ensino de Química, Estágio Supervisionado, Instrumentação para o Ensino de Química, Metodologia para o Ensino de Química e Projetos em Ensino de Química.

O Poço do Visconde ilustra bem algumas características da postura pedagógica de Monteiro Lobato, tais como a valorização do saber por meio da prática, o aluno como sujeito ativo no processo de aprendizagem, o saber movido por meio de temas significativos nos quais o conhecimento surge como necessidade de resposta a uma determinada pergunta ou problema a ser resolvido. Assim como apresenta características relacionadas à possibilidade de promover aspectos humanos em discussões onde a ciência se faz presente, por meio da fala e ação de personagens inseridos em contextos que revelam aspectos não visíveis em textos específicos de ciência.

Cabe ressaltar que o texto literário não deve ser utilizado de forma utilitarista e nada substitui a leitura do livro e a 
experiência que podemos ter, por meio da imersão no âmago do texto, da história e da completude da obra. Entretanto, como os livros de Monteiro Lobato, em geral, apresentam capítulos curtos, na maioria das vezes, com temáticas que podem ser problematizadas sem se configurar num recorte que desestimule a leitura completa do livro, entendemos que os mesmos podem ser utilizados nas disciplinas pedagógicas das licenciaturas em Química, como textos geradores de discussões a respeito dos aspectos didáticos, metodológicos e práticos do ensinar química.

A análise que fizemos, também permite interpretar que a leitura de $O$ Poço do Visconde pode potencializar discussões a respeito do significado de curiosidade ingênua e epistemológica na pedagogia de Paulo Freire e o papel delas no processo de ensino e aprendizagem, assim como permite destacar uma proposta de ensino de conceitos específicos de ciências a partir de um tema gerador de interesse às crianças do sítio - o petróleo - e a importância da problematização em uma pedagogia que privilegia a dúvida e a pergunta, conforme discutimos nos pressupostos pedagógicos e epistemológicos de Paulo Freire.

Como já mencionamos no caso específico do livro $O$

Poço do Visconde, encontramos vários elementos importantes para discussão a respeito da ciência, do seu ensino, do seu fazer e da sua relação com a sociedade a partir das diferentes visões, posturas e atitudes em relação à ciência e ao conhecimento científico que cada uma das personagens apresenta nas estórias do escritor. Por isso, entendemos que O Poço do Visconde pode potencializar discussões pedagógicas sobre o ensino de química no contexto da formação de professores.

Por fim, consideramos que as pesquisas centradas no estudo das relações entre literatura e ciência, também devem avançar no sentido de promover investigações sobre o uso de textos literários no contexto da formação inicial de professores e na Educação Básica, no sentido de desenvolver e avaliar formas de trabalhar o texto nas aulas de química e analisar a recepção dos licenciandos e alunos do Ensino Médio com relação à literatura.

\section{Referências}

ABREU, T.M.C.S.N. de. Um Lobato educador: sob o prisma da fecundidade da obra infantil lobatiana. Dissertação de Mestrado UFPE: Recife, 2004.

ALMEIDA, M.J.P.M. de e SILVA, Henrique. C (organizadores). Linguagens, leituras e Ensino da Ciência, Campinas: Mercado das Letras, 1998.

ANDRADE, I.B. de; MARTINS, I. Discursos de professores de ciências sobre leitura. In: Anais do IX Encontro Nacional de Pesquisa em Ensino de Física, Jaboticatubas, 2004.

APÓSTOLO NETTO, J. O discurso cientificista no livro 'A Chave do Tamanho’ de Monteiro Lobato. Pós-História, Assis, n. 4, 1996.
ARAPIRACA, M.A. Prólogo de uma Paidéia Lobatiana fundada no fazer lúdico e especulativo: A chave do tamanho. Tese de DoutoradoUFBA: Salvador, 1996.

BOSI, A. Lobato e a criação literária. Boletim Bibliográfico da Biblioteca Mário de Andrade, V. 43, N. 1, Jan. - Jun., 1982, SP, Departamento de Bibliotecas Públicas.

BRAYNER, F.H.A. Como salvar a educação (e o sujeito) pela literatura: sobre Philippe Meirieu e Jorge Larrosa, Revista Brasileira de Educação, No. 29, Maio/Jun/Jul/Ago, 2005.

CAMENIETZKI, C.Z. O Saber imponente: estudo da noção de ciência na obra infantil de Monteiro Lobato. Dissertação de Mestrado FGV: Rio de Janeiro, 1988.

CANDIDO, A. O direito à literatura. Vários escritos. 3. ed. São Paulo: Duas Cidades, 1995.

CANETTI, E. Uma luz em meu ouvido. São Paulo: Ed. Companhia das letras, 1989.

CARDOSO, R.D. Monteiro Lobato: entre o pedagógico e o estético. Tese de Doutorado. UNESP: Assis, 2007.

CARVAlHO, F.A. de. Outros... Com textos e passagens: traços biológicos em obras de Monteiro Lobato. Dissertação de Mestrado - Unicamp: Campinas, 2002.

CATINARI, A.F. Monteiro Lobato e o projeto de educação interdisciplinar. Dissertação de Mestrado - UFRJ: Rio de Janeiro, 2006.

CECCANTINI, J.L.; MARTHA, A.A.P. (Organizadores). Monteiro Lobato e o leitor de hoje, São Paulo: Cultura Acadêmica, 2008.

CHIARADIA, K. O poço do Visconde: o faz-de-conta quase de verdade. In LAJOLO, M.;

DEYLlOT, M.E.C. Ler Palavras, Conceitos e o Mundo: o desafio de entrelaçar duas culturas em um convite à física. Dissertação de Mestrado - USP: São Paulo, 2005.

FERREIRA, J.C.D. Aproximação entre a obra de Júlio Verne e o Ensino de Física. Dissertação de Mestrado - UNESP: Presidente Prudente, 2011.

FLÔR, C.C. Leitura e formação de leitores em aulas de química no Ensino Médio. Tese de Doutorado - UFSC: Florianópolis, 2009.

FRANCISCO JÚNIOR, W.E. Estratégias de leitura e educação química: que relações? Química Nova na Escola, v. 32, n. 4, novembro, 2010.

FREIRE, P. Pedagogia do oprimido. 13. ed. Rio de Janeiro: Paz e Terra, 1983.

À Sombra desta mangueira. São Paulo: Editora Olho d'água, 1995.

Por uma pedagogia da pergunta, Rio de Janeiro: Editora Paz e Terra, 5. ed. 2002.

. A importância do ato de ler: em três artigos que se completam, São Paulo: Editora Cortez, 50. ed. 2009a.

Pedagogia da autonomia: saberes necessários à prática educativa, São Paulo: Paz e Terra, 39. ed, 2009b.

GALVÃO, C. Ciência na literatura e literatura na ciência. Interacções, №. 3, 2006. Disponível em http://nonio.eses.pt/interaccoes/artigos/ C3.pdf. Acesso em 21 de agosto de 2009.

GOIS JUNIOR, E. Higienismo e positivismo no Brasil: unidos e separados nas campanhas sanitárias $(1900$ - 1930). Dialogia, 2, 21-32, 2003. 
GOMES, E.F. O romance e a teoria da relatividade: a interface entre literatura e ciência no ensino de física através do discurso e da estrutura da ficção. Dissertação de Mestrado - USP: São Paulo, 2011.

GONÇALVES, F.P. Experimentação e literatura: contribuições para a formação de professores de química. Química Nova na Escola, Vol. 36, $\mathrm{N}^{\circ} 2$, p. 93-100, 2014.

GROTO, S.R. Literatura de Monteiro Lobato no ensino de ciências. Dissertação de Mestrado, Natal, Universidade Federal do Rio Grande do Norte, 2012.

GROTO, S.R.; MARTINS, A.F.P. Monteiro Lobato em aulas de ciências: aproximando ciência e literatura na educação científica. Ciência \& Educação, Bauru, V.21, p. 219 - 238, 2015a.

. A literatura de Monteiro Lobato na discussão de questões acerca da natureza da ciência no ensino fundamental. Revista Ensaio, Belo Horizonte, V.17, N.2, p. 390 - 413, Maio-Ago., 2015b.

LOBATO, M. Obras Completas de Monteiro Lobato - O Poço do Visconde. São Paulo: Editora Brasiliense, 1957.

Conferências, Artigos e Crônicas. Obras Completas de Monteiro Lobato. São Paulo: Editora Brasiliense, 1961.

MACEDO, V.L.V de. O faz-de-conta de Jean Piaget na literatura de Monteiro Lobato. Belo Horizonte: Cuatiara, 1996.

MASSI, L.; SANTOS, G.R. dos; FERREIRA, J.Q.; QUEIROZ, S.L. Artigos científicos como recurso didático no ensino superior de química. Química Nova, v. 32, n. 2, p. 503-510, 2009.

NUNES, L.A. A literatura infantil de Monteiro Lobato e o ideário escolanovista. Revista de Iniciação Científica da FFC, v. 4, n. 2, 2004.

OLIVEIRA, N.R. A presença do teatro no Ensino de Física. Dissertação de Mestrado - USP: São Paulo, 2004.

OLIVEIRA, A.A. Física e Ficção Científica: desvelando mitos culturais em uma educação para a liberdade. Dissertação de Mestrado - USP: São Paulo, 2011.

OLIVEIRA, L. S. de. A perspectiva científica de Monteiro Lobato na obra O poço do Visconde: um estudo à luz da História da Ciência. Tese de Doutorado - PUC/SP, São Paulo: 2011.

PEREIRA, R.B. Memórias do Visconde de Sabugosa, Dissertação de Mestrado - UNICAMP, Campinas, 2006.

PIASSI, L.P. Contatos: a ficção científica no Ensino de Ciências em um contexto sociocultural. Tese de Doutorado - FEUSP: São Paulo, 2007.

A perspectiva sociocultural da física nos romances de ficção científica de Arthur Clarke, Revista Brasileira de Pesquisa em Educação em Ciências, v. 11, n. 2, 2011.

PINTO, G.A. Divulgação científica como literatura e o ensino de ciências. Tese de Doutorado - FEUSP: São Paulo, 2007.

PINTO NETO, P.C. Ciência, Literatura e Civilidade. Tese de Doutorado - UNICAMP: Campinas, 2001.

. Júlio Verne: o propagandista das ciências. Ciência \& Educação, n. 12, dezembro, 2004.
A Química Segundo Primo Levi. In: Anais do XIV Encontro Nacional de Ensino de Química. Curitiba, 2008. Disponível em http://www.quimica.ufpr.br/eduquim/eneq2008/resumos/R0880-1. pdf. Acesso em 21 de agosto de 2009.

PORTO, P.A. Augusto dos Anjos: ciência e poesia. Química Nova na Escola, n. 11, maio, 2000.

PORTO, P.A.; LAKATOS, V.K.; TIEDEMANN, P.W. Primo Levi and The Periodic Table: Teaching Chemistry using a Literary Text. Journal of Chemical Education, v. 84, n. 5, maio, 2007.

SANTOS, G.R; QUEIROZ, S.L.; SÁ, L.P. Uso de artigos científicos em uma disciplina de Físico-química. Química Nova, v. 29, n. 5, p. 1121-1128, 2006.

RICARDO, E.C. Problematização a contextualização no ensino das ciências: acerca das ideias de Paulo Freire e Gérard Fourez. In: Anais do IV Encontro Nacional de Pesquisa em Educação em Ciências, Bauru, 2003.

QUEIROZ, S.L; SÁ, L.P. Promovendo a argumentação no ensino superior de química. Química Nova, v. 30, p. 2035-2042, 2007.

SALOMÃO, S.R. Lições de Botânica: um ensaio para as aulas de ciências, Tese de Doutorado, Rio de Janeiro, UFF, 2005.

SANTOS, Elisângela da Silva. Monteiro Lobato e suas seis personagens em busca da nação. Dissertação de Mestrado - UNESP: Marília, 2008.

SANTOS, T.P. dos. Concepções de Ciência nas Obras de Monteiro Lobato: mapeamento e análise de termos científicos no livro Serões de Dona Benta. Dissertação de Mestrado - UNESP: Bauru, 2011.

SCAVONE, A.C. Reflexos do Positivismo em A Chave do Tamanho. In: Letras de Hoje, n. 43, Rio Grande do Sul: PUC, março, 1981.

SILVA. C.S. da. Poesia de António Gedeão e a formação de professores de química. Química Nova na Escola, v. 33, n. 2, maio, 2011.

SOLINO, A.P.; GEHLEN, S.T. O papel da problematização freireana em aulas de ciências/física: articulações entre a abordagem temática freireana e o ensino de ciências por investigação, Ciência \& Educação, Bauru, v. 21, n. 4, p. 911-930, 2015.

TEIXEIRA, A.S. Pequena introdução à filosofia da educação: a escola progressiva ou a transformação da escola, Rio de Janeiro: Editora UFRJ, 2007.

TEIXEIRA JÚNIOR, J.G.; SILVA, R.M.G. da. Perfil de Leitores em um curso de Licenciatura. Química Nova, v. 30, n. 5, 1365-1368, 2007.

VALENTE, T.A. Uma chave para A chave do tamanho de Monteiro Lobato. Dissertação de Mestrado - UNESP: Assis, 2004.

VIERNE, S. Ligações tempestuosas: a ciência e a literatura. In: CORBOZ, A. etal. Ciência e imaginário. Brasília: Editora da UnB, 1994. Tradução de: Ivo Martinazzo.

ZANETIC, J. Literatura e cultura científica. In: ALMEIDA, M.J.P.M. de; SILVA, H.C. da (orgs.). Linguagens, leituras e ensino da ciência. Campinas: Mercado de Letras; Associação de Leitura do Brasil ALB, 1998.

Física e arte: uma ponte entre duas culturas. Pro-Posições, v. 17, n. 1 (49) - janeiro/abril, 2006. 